\title{
The distribution and stabilisation of dissolved Fe in deep-sea hydrothermal plumes
}

\author{
Sarah A. Bennett ${ }^{\text {a,* }}$, Eric P. Achterberg ${ }^{\text {a }}$, Douglas P. Connelly ${ }^{\text {a }}$, Peter J. Statham ${ }^{\text {a }}$, \\ Gary R. Fones ${ }^{\mathrm{a}, 1}$, Christopher R. German ${ }^{\mathrm{a}, \mathrm{b}}$ \\ ${ }^{a}$ National Oceanography Centre, Southampton, SO14 3ZH, UK \\ ${ }^{\mathrm{b}}$ Woods Hole Oceanographic Institution, Woods Hole, MA 02543, USA
}

Received 19 October 2007; received in revised form 21 January 2008; accepted 31 January 2008

Available online 19 February 2008

Editor: H. Elderfield

\begin{abstract}
We have conducted a study of hydrothermal plumes overlying the Mid-Atlantic Ridge near $5^{\circ} \mathrm{S}$ to investigate whether there is a significant export flux of dissolved Fe from hydrothermal venting to the oceans. Our study combined measurements of plume-height Fe concentrations from a series of 6 CTD stations together with studies of dissolved Fe speciation in a subset of those samples. At $2.5 \mathrm{~km}$ down plume from the nearest known vent site dissolved Fe concentrations were $\sim 20 \mathrm{nM}$. This is much higher than would be predicted from a combination of plume dilution and dissolved Fe(II) oxidation rates, but consistent with stabilisation due to the presence of organic Fe complexes and Fe colloids. Using Competitive Ligand Exchange-Cathodic Stripping Voltammetry (CLE-CSV), stabilised dissolved Fe complexes were detected within the dissolved $\mathrm{Fe}$ fraction on the edges of one non-buoyant hydrothermal plume with observed ligand concentrations high enough to account for stabilisation of $\sim 4 \%$ of the total Fe emitted from the $5^{\circ} \mathrm{S}$ vent sites. If these results were representative of all hydrothermal systems, submarine venting could provide $12-22 \%$ of the global deep-ocean dissolved Fe budget.
\end{abstract}

(C) 2008 Elsevier B.V. All rights reserved.

Keywords: hydrothermal vent; iron; Fe; ligands; organic; mid-ocean ridge

\section{Introduction}

Although it has long been recognised that Fe acts as an essential micronutrient for phytoplankton growth (Morel et al., 2004; Pollard et al., 2007), the debate over its sources and sinks persists (Ussher et al., 2004). One potential source of Fe to the surface ocean is through upwelling of dissolved Fe released from deep-sea hydrothermal vents (Coale et al., 1991; Boyle et al., 2005) — but this would require dissolved Fe to be stabi-

\footnotetext{
* Corresponding author: Tel.: +44 2380 596003; fax: +44 2380596149. E-mail address: saroban@noc.soton.ac.uk (S.A. Bennett).

${ }^{1}$ Now at School of Earth and Environmental Sciences, University of Portsmouth, Portsmouth, PO1 3QL, UK.
}

lised in some form as it disperses away from a vent-site. This appears problematic because when vent-fluids first enter the base of the water column abundant polymetallic particulate phases are formed: predominantly Fe-rich sulfides and $\mathrm{Fe}$ oxyhydroxides (Feely et al., 1987). In earlier work, it was often assumed that hydrothermal inputs of dissolved Fe to the deepocean should be negligible (Mottl and McConachy, 1990; German et al., 1991). More recently, however, it has been recognised that dissolved $\mathrm{Fe}(\mathrm{II})$ oxidation rates vary systematically along the thermohaline conveyor; and in the Pacific and Indian Oceans a significant proportion of hydrothermallysourced dissolved Fe(II) can persist at least as far as nonbuoyant plume height (Field and Sherrell, 2000; Statham et al., 2005). Is it possible, therefore, that a significant flux of dissolved $\mathrm{Fe}$, originating from hydrothermal vents, may be exported to the deep-ocean? 
Fe exists at concentrations greater than the predicted solubility in both the surface and deep-ocean (Millero, 1998) and $>99 \%$ of dissolved $\mathrm{Fe}(\mathrm{dFe}$, that fraction passing through a $0.4 \mu \mathrm{m}$ filter (Cullen et al., 2006)) is complexed by stable organic ligands (Gledhill and Van den Berg, 1994; Rue and Bruland, 1997; Van den Berg, 2006). Organic Fe complexation will reduce the reactivity of the $\mathrm{Fe}$ species, preventing precipitation of $\mathrm{Fe}$ and scavenging into/onto particulate phases. In the deep open-ocean an average concentration of $0.7 \mathrm{nM}$ dissolved $\mathrm{Fe}$ exists (ranging from 0.4 to $1 \mathrm{nM}$ )(Bergquist and Boyle, 2006) in association with Fe binding ligands that are present in concentrations ranging from 0.7 to $1.4 \mathrm{nM}$, with conditional stability constants ( $\left.\log \mathrm{K}_{\mathrm{Fe}^{\prime} \mathrm{L}}^{\prime}\right)$ ranging from 11.4 to 12.2 (Boye et al., 2001; Cullen et al., 2006). These high $\mathrm{K}_{\mathrm{Fe}^{\prime} \mathrm{L}}^{\prime}$ values, it is argued, indicate a biological (hence, organic) origin for part of this ligand fraction (van Leeuwen and Town, 2005).

Organic interaction with hydrothermal Fe has been suggested previously, from a study of dissolved $\mathrm{Fe}$ (II) oxidation rates in nonbuoyant hydrothermal plumes overlying the Central Indian Ridge (Statham et al., 2005). More recently, measurements of a decreased fraction of reactive $\mathrm{Fe}$ in the vent fluids at the Logatchev vent-site $\left(15^{\circ} \mathrm{N}\right.$, Mid-Atlantic Ridge) has been used to speculatively suggest increased complexation of $\mathrm{Fe}$, for example with sulfur or organic compounds (Schmidt et al., 2007). Such complexes, if formed within buoyant hydrothermal plumes, would certainly have the potential to sustain enhanced dissolved $\mathrm{Fe}$ concentrations at least as far as non-buoyant plume height.

Exploration for, and study of, hydrothermal systems along the southern Mid-Atlantic Ridge was initiated to test the hypo- theses concerning what controls the biogeography and biodiversity of vent-fauna around the global ridge-crest (Van Dover et al., 2002). Once located, however, the $5^{\circ} \mathrm{S}$ area has provided an ideal natural laboratory for the study of Fe stabilisation in non-buoyant hydrothermal plumes because the study area is geographically intermediate between the Logatchev and Indian Ocean hydrothermal systems: at $5^{\circ} \mathrm{S}$ on the Southern MidAtlantic Ridge (German and Parson, 2005).

\section{Geological setting and sample collection}

All samples for this work were collected during RRS Charles Darwin Cruise CD169 in March 2005 from non-buoyant hydrothermal plumes overlying the Southern Mid-Atlantic Ridge near $5^{\circ} \mathrm{S}$ (German and Parson, 2005). These plumes were in the locality of three known high-temperature vent fields: Red Lion, Turtle Pits and Comfortless Cove (Koschinsky et al., 2006b; Haase et al., 2007; German et al., submitted for publication), all of which are located within $2 \mathrm{~km}$ of each other and close to the axial summit of a 2 nd order segment of this slow-spreading ridge (Fig. 1).

Water column samples were collected using 10-L externallysprung Niskin bottles mounted on a 24 position rosette frame fitted with a SeaBird SBE 9/11+CTD. Samples were collected with the aid of real-time feedback from an in situ transmissometer (Chelsea Alphatracka MKII, path length $25 \mathrm{~cm}$ ), interfaced to the SeaBird CTD.

On recovery of the CTD-rosette on-deck, an initial suite of water samples were drawn directly into acid-cleaned $1 \mathrm{~L}$ low

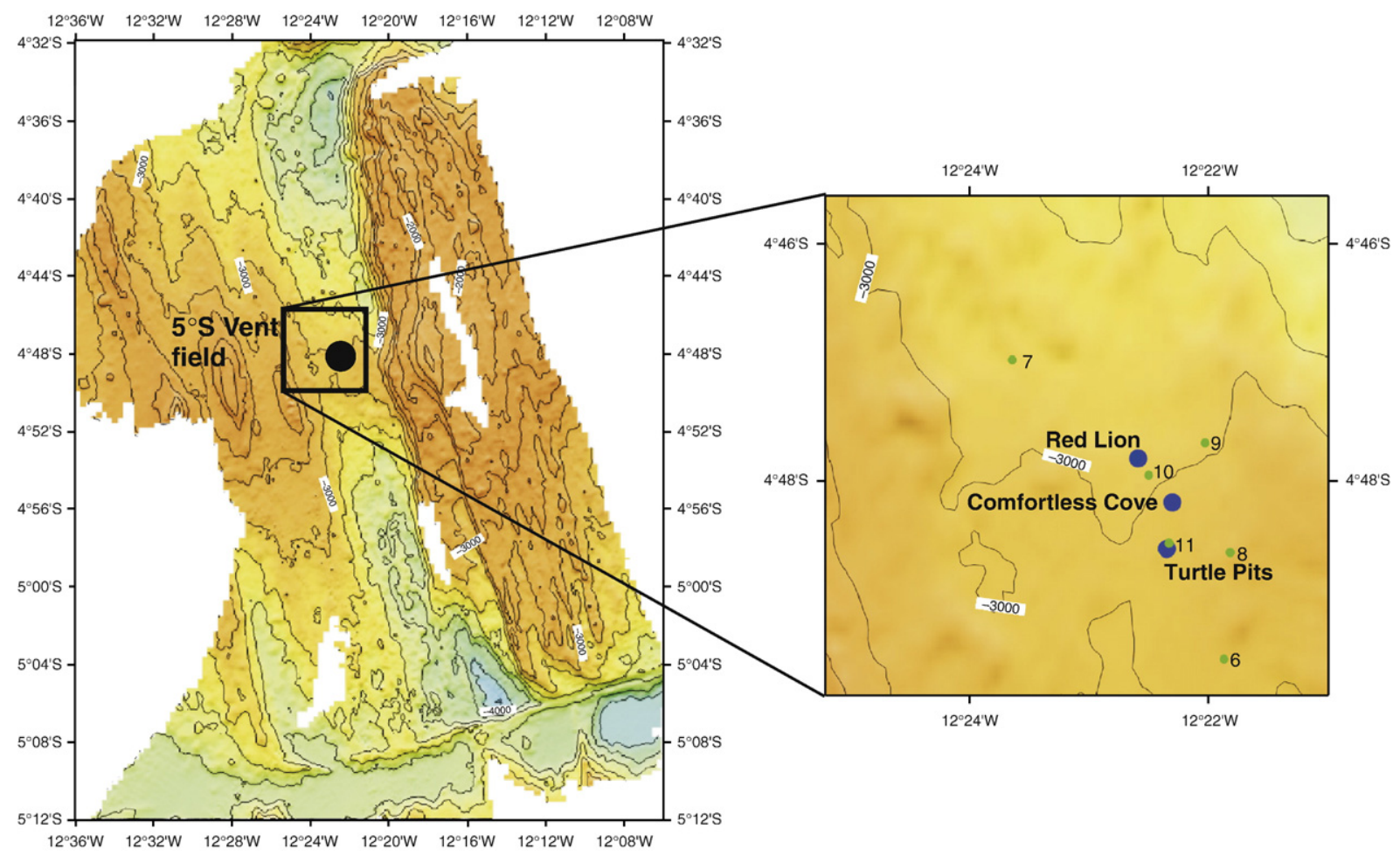

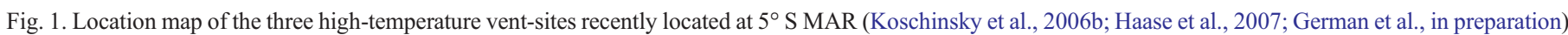
together with locations of CTD-stations occupied for this study (German and Parson, 2005). 
density polyethylene (LDPE, Nalgene) bottles (following 3-fold rinsing) for the analysis of total dissolvable Fe and $\mathrm{Mn}$ (TdFe and TdMn). Each Niskin bottle was then transferred to a cleanlaboratory container on-board the ship, where further water samples were taken by filtration under pressure $\left(\mathrm{N}_{2}\right.$ gas) through an acid cleaned $0.4 \mu \mathrm{m}$ membrane filter (Whatman, polycarbonate, $47 \mathrm{~mm}$ ). The filtrate was collected into acid cleaned $125 \mathrm{ml}$ LDPE bottles for the analysis of dissolved $\mathrm{Fe}(\mathrm{dFe})$. All samples were subsequently acidified with Quartz sub-boiled distilled nitric acid (to $\mathrm{pH} 1.6$ ) with the exception of a sub-sample of the filtered water $(500 \mathrm{ml})$ that was taken from selected Niskin bottles, collected in acid cleaned Teflon bottles and immediately frozen for shore-based speciation studies (Gledhill and Van den Berg, 1994; Rue and Bruland, 1995; Van den Berg, 2006). Samples were selected based on the transmissometer profile, sampling top-to-bottom across the full thickness of a pronounced particlerich, non-buoyant plume. All further analysis was carried out onshore at the National Oceanography Centre, Southampton, UK.

\section{Laboratory methods}

\subsection{Quantification of $\mathrm{Fe}$ and $\mathrm{Mn}$}

Fe and Mn measurements were carried out using Graphite Furnace Atomic Absorption Spectroscopy (GFAAS) after a preconcentration step. This involved chelation of the metals in the seawater sample with ammonium 1-pyrrolidine dithiocarbamate (APDC, Aldrich) and diethyldithiocarbamic acid, as the diethyl ammonium salt (DDDC, Aldrich), followed by solvent extraction with HPLC grade chloroform $\left(\mathrm{CHCl}_{3}\right.$, Fisher) and back extraction into quartz distilled concentrated $\mathrm{HNO}_{3}$ (Fisher) (Bruland et al., 1979; Statham, 1985). GFAAS measurements were carried out using a Perkin Elmer AAnalyst 800 Atomic Absorption Spectrometer and calibration was carried out with a diluted $1000 \mu \mathrm{g} / \mathrm{L} \mathrm{Fe}$ and Mn standard (Sigma Aldrich). The method was validated with a certified reference material and the detection limit was $1.2 \mathrm{nM}$ for $\mathrm{Fe}$ and $0.18 \mathrm{nM}$ for $\mathrm{Mn}$ $(n=3)$. The detection limit was calculated from blank analysis of sub-boiled distilled water treated in the same way as the samples.

\subsection{Speciation analysis of $d F e$}

\subsubsection{Overview of the CLE-CSV technique}

CLE-CSV analysis was carried out on selected plume samples to determine the presence of $\mathrm{Fe}$ stabilising ligands, assuming that any unbound inorganic $\mathrm{Fe}(\mathrm{II})$ in this Atlantic setting would have been oxidised by the time of sampling (Rudnicki and Elderfield, 1993). The technique uses a competitive reaction between the natural ligands present in a sample and an added, well-characterised, synthetic ligand. For this purpose, the sample was titrated with $\mathrm{Fe}(\mathrm{III})$, in the presence of TAC, enabling the determination of the stability constant of any unbound or competitively released ligands. The overall total ligand concentration, $[L]$ (which includes both complexed and uncomplexed free organic ligands, inorganic colloidal ligands and crystalline Fe hydrolysis products (Gledhill and Van den Berg, 1995)) can then be calculated from equilibrium principles (Ruzic, 1982; Van den Berg, 1982). The theory for CLE-CSV has been described in detail in a number of prior publications (Gledhill and Van den Berg, 1994; Van den Berg, 1995; Wu and Luther, 1995; Croot and Johansson, 2000) but is restated succinctly, below.

The equilibrium between the natural ligands present in seawater and the Fe present is expressed by:

$\mathrm{Fe}^{\prime}+L^{\prime} \leftrightarrow \mathrm{Fe} L$

Where $L^{\prime}$ is the free organic ligand within the system, $\mathrm{Fe}^{\prime}$ is the labile $\mathrm{Fe}$ i.e. $\mathrm{Fe}^{3+}$ species not bound in strong complexes, and $\mathrm{Fe} L$ is the Fe ligand complex. The conditional stability constant for the formation of the complex $\mathrm{Fe} L\left(K_{\mathrm{Fe}^{\prime} L}^{\prime}\right)$ is defined as:

$K^{\prime}{ }_{\mathrm{Fe}^{\prime} L}=[\mathrm{Fe} L] /\left[\mathrm{Fe}^{\prime}\right] \times\left[L^{\prime}\right]$

Where $K^{\prime}{ }_{\mathrm{Fe}^{\prime} L}$ is the conditional stability constant with respect to $\mathrm{Fe}^{\prime}$ (Croot and Johansson, 2000). On addition of a competing ligand, 2-(2thiazolylazo)-p-cresol (TAC), a new equilibrium is set up and the TAC ligand competes with natural ligands for the complexation of the labile fraction of $\mathrm{Fe}^{\prime}$ in the sample i.e. the weakly bound organic species in the $\mathrm{Fe} L$ fraction as well as inorganic Fe species (Gledhill and Van den Berg, 1994). The Fe $(\mathrm{TAC})_{2}$ complex is electrochemically active and therefore can be detected by CSV.

The concentration of $\mathrm{Fe} L$ can be calculated at each level of $\mathrm{Fe}$ addition during the titration. This requires knowledge of the total $\mathrm{Fe}$ concentration in the sample i.e. Fe initially present plus $\mathrm{Fe}$ added during the titration, and subtracting the $\mathrm{Fe}(\mathrm{TAC})_{2}$ concentration. CSV determines a current $\left(I_{\mathrm{p}}\right)$ which relates to the concentration of $\mathrm{Fe}(\mathrm{TAC})_{2}$ via the sensitivity, $S$ :

$I_{\mathrm{p}}=S \times\left[\mathrm{Fe}(\mathrm{TAC})_{2}\right]$

$S$ can be obtained from the gradient ( $I_{\mathrm{p}}$ vs added Fe) at enhanced concentrations of total $\mathrm{Fe}$ when all the natural organic ligands are saturated and a straight line is observed. A curvature will be observed at low Fe additions because the added Fe will complex initially with any free (non Fe-bound) ligands.

The total ligand concentration and the conditional stability constant can be solved using the Langmuir transformation method (or Van den Berg/Ruzic transformation) based on the following linear equation (Ruzic, 1982; Van den Berg, 1982):

$\left[\mathrm{Fe}^{3+}\right] /[\mathrm{Fe} L]=\left[\mathrm{Fe}^{3+}\right] / C_{L}+1 /\left(K^{\prime}{ }_{\mathrm{Fe} L} C_{L}\right)$

Where $C_{L}$ is the total natural ligand and $K_{\mathrm{Fe} L}^{\prime}$ is the conditional stability constant with respect to $\mathrm{Fe}^{3+}$. $\left[\mathrm{Fe}^{3+}\right]$ is directly related to the $\mathrm{Fe}(\mathrm{TAC})_{2}$ concentration by $\alpha^{\prime}$ :

$\left[\mathrm{Fe}^{3+}\right]=\left[\mathrm{Fe}(\mathrm{TAC})_{2}\right] / \alpha^{\prime}$

Where $\alpha^{\prime}$ is the overall $\alpha$ coefficient for inorganic complexation and complexation by TAC i.e. $\alpha^{\prime}=\alpha_{\mathrm{Fe}}^{\prime}+\alpha_{\mathrm{Fe}(\mathrm{TAC})_{2}}^{\prime}$ In this study, the inorganic side reaction coefficient for $\mathrm{Fe}^{\prime}$ was taken as $\log \alpha^{\prime}{ }_{\mathrm{Fe}}=$ 10 and for $\mathrm{TAC}$ as $\log \alpha_{\mathrm{Fe}(\mathrm{TAC}) 2}^{\prime}=12.4$ (Rue and Bruland, 1995; Croot and Johansson, 2000) and therefore $\alpha^{\prime}$ can be calculated. Using Eq. (5) to substitute for $\mathrm{Fe}^{3+}$ in Eq. (4), is convenient as a 
current proportional to the $\mathrm{Fe}(\mathrm{TAC})_{2}$ concentration is measured during the experiment. Final substitution and rearrangement results in Eq. (7), which is suitable for solving $C_{L}$ and $K_{\mathrm{Fe}^{\prime} L}^{\prime}$.

$\left[\mathrm{Fe}(\mathrm{TAC})_{2}\right] /[\mathrm{Fe} L]=\left[\mathrm{Fe}(\mathrm{TAC})_{2}\right] / C_{L}+\alpha^{\prime} /\left(K^{\prime}{ }_{\mathrm{Fe} L} C_{L}\right)$

$\left[\mathrm{Fe}^{\prime}\right] /[\mathrm{Fe} L]=\left[\mathrm{Fe}^{\prime}\right] / C_{L}+1 /\left(K^{\prime}{ }^{\prime} e^{\prime} L C_{L}\right)$

Therefore the ratio of $\left[\mathrm{Fe}^{\prime}\right] /[\mathrm{Fe} L]$ can be plotted against $\left[\mathrm{Fe}^{\prime}\right]$ giving a straight line and the $\mathrm{y}$ intercept and slope of the line can be used to obtain $K_{\mathrm{Fe}^{\prime} L}^{\prime}$ and $C_{L}$ (Rue and Bruland, 1995):

Slope $=1 / C_{L}$

$y-$ intercept $=1 /\left(K^{\prime}{ }_{\mathrm{Fe}^{\prime} L} C_{L}\right)$

\subsubsection{Titration procedure for ligand determination}

The titration procedure closely followed that of Croot and Johansson (2000), with overnight defrosting and gentle mixing of the frozen samples. In a laminar flow hood, multiple $10 \mathrm{ml}$ sub-samples of the defrosted filtered seawater were pipetted into a series of Teflon pots ( $25 \mathrm{ml}$, Nalgene) and each sample was treated identically, as described below, with a 15 min time-lag between the processing of each successive sub-sample. First, samples were buffered using $1 \mathrm{M} \mathrm{N}$-(2-hydroxyethyl)piperazine- $N^{\prime} ;$-2-propanesulfonic acid (EPPS, $\mathrm{pH}$ 8) that had been cleaned using a Chelex-100 column (Donat and Bruland, 1988) and then titrated with $\mathrm{Fe}$ ranging from 0 to $20 \mathrm{nM}(0-30 \mathrm{nM}$ for the more concentrated samples). Next, the Fe was allowed to equilibrate for $1 \mathrm{~h}$ at room temperature and at the end of this period $10 \mu \mathrm{l}$ of $10 \mathrm{mM}$ TAC was added. The samples were then left to equilibrate overnight in a laminar flow hood.

The following day, voltammetric measurements were undertaken using a Metrohm VA 663 Stand with a Hanging Mercury Drop Electrode (HMDE), glassy carbon working electrode, $\mathrm{Ag} /$ $\mathrm{AgCl}$ reference electrode and a $\mu$ Autolab potentiostat (Ecochemie, NL). Each sample was de-aerated for 3 min with

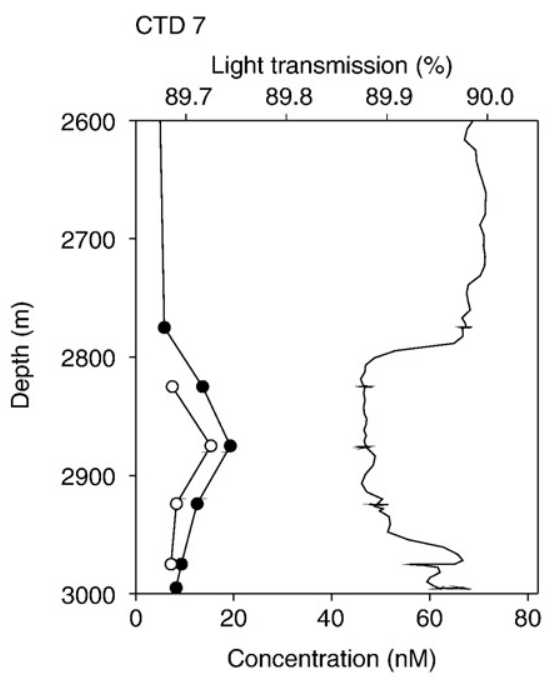

CTD 10

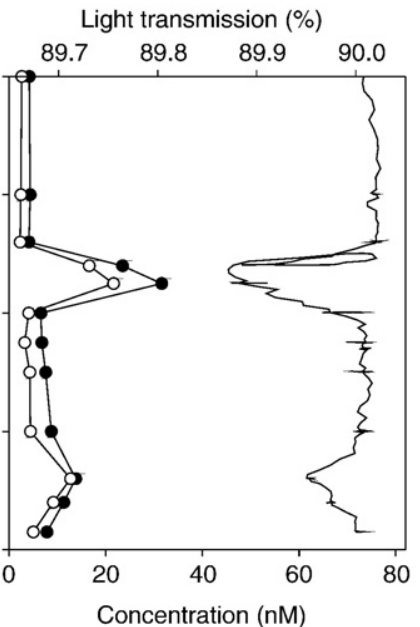

CTD 11

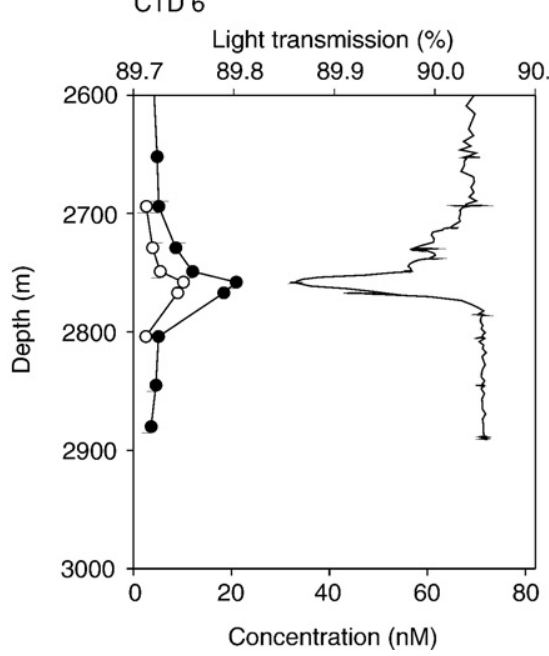

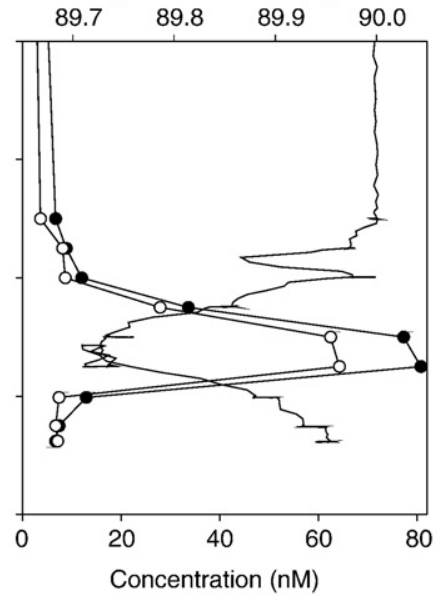

CTD 9

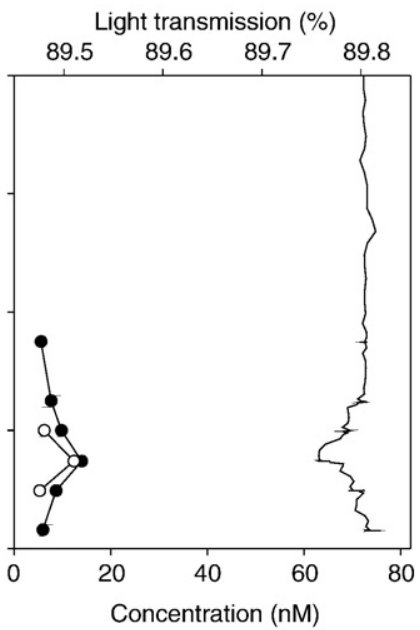

CTD 8

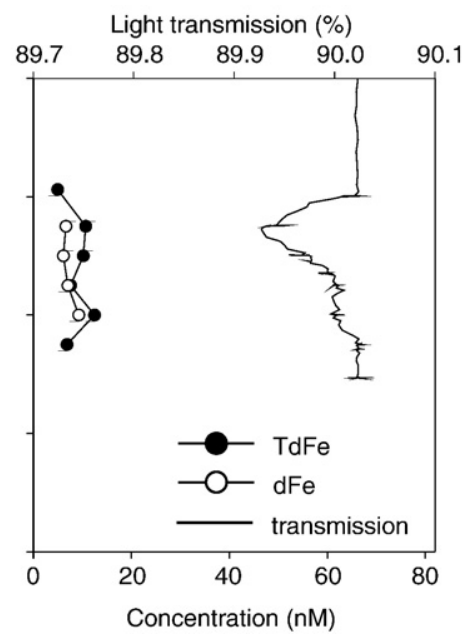

Fig. 2. Vertical depth profiles of Fe concentrations and light transmission for stations that intercepted non-buoyant hydrothermal plumes at the $5^{\circ} \mathrm{S}$ Segment, MAR (2600-3000 m depth). Closed circles represent total dissolvable $\mathrm{Fe}$ ( $\mathrm{TdFe}$ ) concentrations, while open circles are for dissolved Fe (dFe) concentrations measured in filtered seawater samples. The solid line on the right hand side of each plot indicates light transmission (\%) detected in real-time, in situ, and used to guide Niskinbottle sampling. 
nitrogen gas and the $\mathrm{Fe}(\mathrm{TAC})_{2}$ complexes were then adsorbed onto a fresh $\mathrm{Hg}$ drop using a deposition potential of $-0.35 \mathrm{~V}$ with an adsorption time of $600 \mathrm{~s}$. Subsequently, a potential scan was undertaken using differential pulse voltammetry. The stripping current from the adsorbed $\mathrm{Fe}(\mathrm{TAC})_{2}$ was recorded at an electrode potential of $-0.41 \mathrm{~V}$. The Teflon voltammetric cell was rinsed with deionised water between the analysis of each sub-sample and sub-samples were run in order of increasing Fe additions.

\subsubsection{CLE-CSV considerations}

Previously, CLE-CSV has only been used in organically dominated oceanic systems. Therefore, to confirm that no false positives occurred due to the presence of inorganic colloids in the hydrothermal plumes studied here, it was important to validate the organic nature of any ligand detected. By using UV digested open-ocean seawater we have been able to investigate a purely inorganic system (Van den Berg, 2005) which, when treated by adding an inorganic Fe(II) spike (Statham et al., 2005) and allowing its oxidation, mimics the inorganic aspects of a hydrothermal system. Repeated CLE-CSV analyses at increasing times after the first $\mathrm{Fe}$ addition have confirmed an absence of any organic ligands in the synthetic system, thereby providing us with strong evidence that a fraction of the ligands observed within our natural hydrothermal plume samples must indeed be organic in nature (Town and van Leeuwen, 2005; Van den Berg, 2006).

\section{Results}

Vertical profiles of $\mathrm{TdFe}, \mathrm{dFe}$ and light transmission at the six CTD stations occupied for this study are shown in Fig. 2. The coincidence of both particle anomalies and elevated $\mathrm{Fe}$ concentrations at greater than $100 \mathrm{~m}$ above the seafloor are diagnostic of the presence of non-buoyant hydrothermal plumes in this area. Our CTD stations were occupied at locations ranging between 0.2 and $2.5 \mathrm{~km}$ from the nearest known ventsources (Table 1) and maximum concentrations fell in the range 12-80 nM for TdFe and 9-64 nM for dFe.

Samples from the shallower plume at CTD 10 - the closest station to the Red Lion vents (Table 2)-were also selected for speciation studies. An enlarged section of this CTD cast, showing $\mathrm{dFe}$ and TdMn concentrations together with transmissometer data, is shown in Fig. 3. Descending from above the top of the

Table 1

Distances of CTD-stations from nearest known vent-sites

\begin{tabular}{lllll}
\hline CTD station & Latitude & Longitude & $\begin{array}{l}\text { Nearest } \\
\text { vent source }\end{array}$ & $\begin{array}{l}\text { Range from } \\
\text { nearest source } \\
(\mathrm{km})\end{array}$ \\
\hline 6 & $4^{\circ} 49.50^{\prime} \mathrm{S}$ & $12^{\circ} 21.87^{\prime} \mathrm{W}$ & $\mathrm{TP}$ & 2.0 \\
7 & $4^{\circ} 46.98^{\prime} \mathrm{S}$ & $12^{\circ} 23.64^{\prime} \mathrm{W}$ & $\mathrm{RL}$ & 2.5 \\
8 & $4^{\circ} 48.60^{\prime} \mathrm{S}$ & $12^{\circ} 21.82^{\prime} \mathrm{W}$ & $\mathrm{TP}$ & 1.1 \\
9 & $4^{\circ} 47.68^{\prime} \mathrm{S}$ & $12^{\circ} 22.03^{\prime} \mathrm{W}$ & $\mathrm{RL}$ & 1.0 \\
10 & $4^{\circ} 47.95^{\prime} \mathrm{S}$ & $12^{\circ} 22.50^{\prime} \mathrm{W}$ & $\mathrm{RL}$ & 0.4 \\
11 & $4^{\circ} 48.52^{\prime} \mathrm{S}$ & $12^{\circ} 22.33^{\prime} \mathrm{W}$ & $\mathrm{TP}$ & 0.2 \\
\hline
\end{tabular}

a TP is the Turtle Pits vent site and RL is the Red Lion vent site.
Table 2

Dissolved Fe speciation results

\begin{tabular}{|c|c|c|c|c|c|c|c|}
\hline \multirow{2}{*}{$\begin{array}{l}\text { Depth } \\
\text { (m) }\end{array}$} & \multirow{2}{*}{$\begin{array}{l}{[\mathrm{Fe}]_{\mathrm{d}}} \\
(\mathrm{nM})\end{array}$} & \multicolumn{2}{|c|}{ Titration 1} & \multicolumn{2}{|c|}{ Titration 2} & \multicolumn{2}{|c|}{ Average } \\
\hline & & $\begin{array}{l}{[L]} \\
(\mathrm{nM})\end{array}$ & $\begin{array}{l}\text { Estimated } \\
K_{\mathrm{Fe}^{\prime} L}^{\prime}\end{array}$ & $\begin{array}{l}{[L]} \\
(\mathrm{nM})\end{array}$ & $\begin{array}{l}\text { Estimated } \\
K_{\mathrm{Fe}^{\prime} L}^{\prime}\end{array}$ & $\begin{array}{l}{[L]} \\
(\mathrm{nM})\end{array}$ & $\begin{array}{l}\text { Estimated } \\
K_{\mathrm{Fe}^{\prime} L}^{\prime}\end{array}$ \\
\hline 2739 & 2.3 & 2.52 & 11.04 & n.d. & n.d. & 2.5 & 11.0 \\
\hline 2759 & 16.6 & n.d. & n.d. & n.d. & n.d. & - & - \\
\hline 2775 & 21.6 & n.d. & n.d. & n.d. & n.d. & - & - \\
\hline 2800 & 4.1 & 4.22 & 11.62 & 4.19 & 11.42 & 4.2 & 11.5 \\
\hline 2825 & 3.2 & 3.42 & 11.18 & 3.41 & 10.94 & 3.4 & 11.1 \\
\hline${ }^{\mathrm{a}}$ Seawater & 0.7 & & & & & $\begin{array}{l}0.7- \\
1.4\end{array}$ & $\begin{array}{l}11.4- \\
12.2\end{array}$ \\
\hline
\end{tabular}

$[\mathrm{Fe}]_{\mathrm{d}}$ is the dissolved $\mathrm{Fe}$ concentration $(0.4 \mu \mathrm{m}$ filter $) .[L]$ is the total concentration of natural ligand within the sample and $K_{\mathrm{Fe}^{\prime} L}^{\prime}$ is the stability constant of the complex. The titrations were carried out twice for each sample and $[L]$ and $K^{\prime}{ }_{\mathrm{Fe}^{\prime} L}$, were estimated from langmuir transformation of the titration data. "n.d." indicates that an organic ligand could not be determined (see text for explanation). For the shallowest samples at $2739 \mathrm{~m}$, only the first titration detected a ligand, repeat measurements could not determine a ligand, suggesting degradation of the sample.

${ }^{a}$ Seawater data sourced from (Boye et al., 2001; Bergquist and Boyle, 2006; Cullen et al., 2006).

plume, dissolved Fe concentrations increased from $2.3 \mathrm{nM}$ at $2739 \mathrm{~m}$ to $16.6 \mathrm{nM}$ at $2759 \mathrm{~m}$ and $21.6 \mathrm{nM}$ at $2775 \mathrm{~m}$ - the "core" of the non-buoyant plume. Below this depth, dissolved Fe concentrations decreased to $4.1 \mathrm{nM}$ at $2800 \mathrm{~m}$ and $3.2 \mathrm{nM}$ at $2825 \mathrm{~m}$ (Table 2). TdMn concentrations followed a similar pattern, with concentrations ranging from 2.5 to $29.2 \mathrm{nM}$ (Fig. 3).

Ligands could not be detected in the two "plume-core" samples because the high dissolved Fe concentrations at these locations saturated any Fe binding ligands (Boye et al., 2005). This is an artefact of the CLE-CSV technique which only enables organic ligand detection when ligand concentrations exceed the dissolved Fe concentrations. By contrast, ligands were detected on the upper and lower fringes of the plume. Below the core of the plume, the two deepest samples had total ligand concentrations of $4.2 \mathrm{nM}$ at $2800 \mathrm{~m}$ and $3.4 \mathrm{nM}$ at $2825 \mathrm{~m}$ along with corresponding

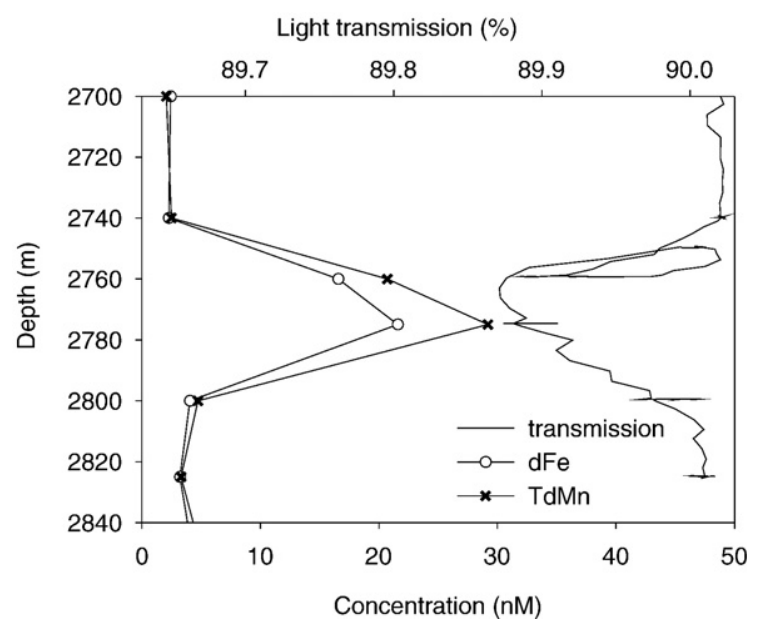

Fig. 3. Depth profiles for dissolved Fe (dFe), total dissolvable Mn (TdMn) and light transmission through the shallower non-buoyant hydrothermal plume at CTD 10 (Fig. 2) which was chosen for CLE-CSV analysis. Crosses: TdMn; open circles: $\mathrm{dFe}$; the solid line on the right hand side of the plot indicates light transmission $(\%)$. 
conditional stability constants of $K_{\mathrm{Fe}^{\prime} L}^{\prime}, 11.5$ and 11.1 (Table 2). Above the core of the plume, the shallowest sample, at $2739 \mathrm{~m}$ depth, had a ligand concentration of $2.5 \mathrm{nM}$ with a corresponding conditional stability constant of $K^{\prime}{ }_{\mathrm{Fe}^{\prime} L} 11.0$.

\section{Discussion}

\subsection{Fe distributions}

The six CTD stations occupied during this study, spanning from North to South across the axial summit at the centre of the $5^{\circ}$ $\mathrm{S}$ ridge-segment (Fig. 1), all exhibited evidence of non-buoyant hydrothermal plumes. Distances from the nearest known vent-site to each station (Table 1) ranged from $0.2 \mathrm{~km}$ (CTD 11) to $2.5 \mathrm{~km}$ (CTD 7). Not surprisingly, the strongest anomalies observed (Fig. 2) were in the profiles for CTD stations $10 \& 11$, occupied at the very centre of the ridge-segment and immediately adjacent to, or directly above, known high-temperature vent-sites (Fig. 1). However, the weakest hydrothermal plume signals were not observed at the most distal CTD stations $(6,7)$ occupied $2 \mathrm{~km} \mathrm{SE}$ and $2.5 \mathrm{~km} \mathrm{NW}$ away from the vent-sites (Figs. 1 and 2). Instead, it was at CTD stations 8 and 9 , occupied just $\sim 1 \mathrm{~km}$ from the ventsites, but offset away from the axis toward the Eastern rift-valley wall, that the weakest plume-signals were observed. These distributions provide strong evidence that along-axis (NW-SE oriented) flow dominates dispersion of non-buoyant plume material within this ridge-segment, with much weaker advection across-axis toward the rift-valley walls.

Another important feature of the data presented in Fig. 2 is that the depths of the non-buoyant plumes observed during each cast were not consistent. Further, close to the segment centre, the profile at CTD 10 revealed evidence for two different hydrothermal plumes at $\sim 2750 \mathrm{~m}$ and $\sim 2950 \mathrm{~m}$. Two processes might cause this. First, the height rise of a buoyant hydrothermal plume is a function of both the local water-column's density stratification and the buoyancy flux associated with any given vent-system (Lupton, 1995). Thus, two discrete vents situated in the same ridge-segment might easily give rise to plumes at two different emplacement heights - either because they were located at different depths on the seafloor or because of different venting intensities. Secondly, once emplaced, non-buoyant hydrothermal plumes do not disperse at a constant depth but along isopycnal (constant density) surfaces. Therefore, during flow over rough topography, or even during the course of a tidal cycle, the observed height of a single non-buoyant plume can routinely vary by $100 \mathrm{~m}$ or more (Rudnicki et al., 1994; Rudnicki and German, 2002). In the latter case, while the depth of a plume might vary, the density at which the plume lies would not. Fig. 4 shows the profiles for CTD stations 10 and 11 replotted against density rather than depth. What is immediately apparent, is that the two plumes observed at station CTD 10 (midway between the Red Lion and Comfortless Cove vent-sites) lie on different isopycnal surfaces from that of the large plume from CTD 11 (occupied directly above the Turtle Pits vent-site). Thus, our near-vent plume data offer clear evidence for three discrete plumes, each sourced by a different hydrothermal vent. This is entirely consistent with the three high-temperature vent-sites now known to exist on the underlying, axial-summit floor (Haase et al., 2007), as well as the potential for further undiscovered vents in this area.

Down-plume, away from sites of active venting, multiple plume-layers that formed close to a vent-site typically coalesce through vertical mixing resulting in a single broad hydrothermal plume (German et al., 1996). This is apparent in the current study at CTD 7 which exhibits a broad, particle-rich maximum extending from $\sim 2750$ to $2950 \mathrm{~m}$ depth, at a distance of $\sim 2.5 \mathrm{~km}$ downplume from the nearest vent-site (Red Lion). What is particularly
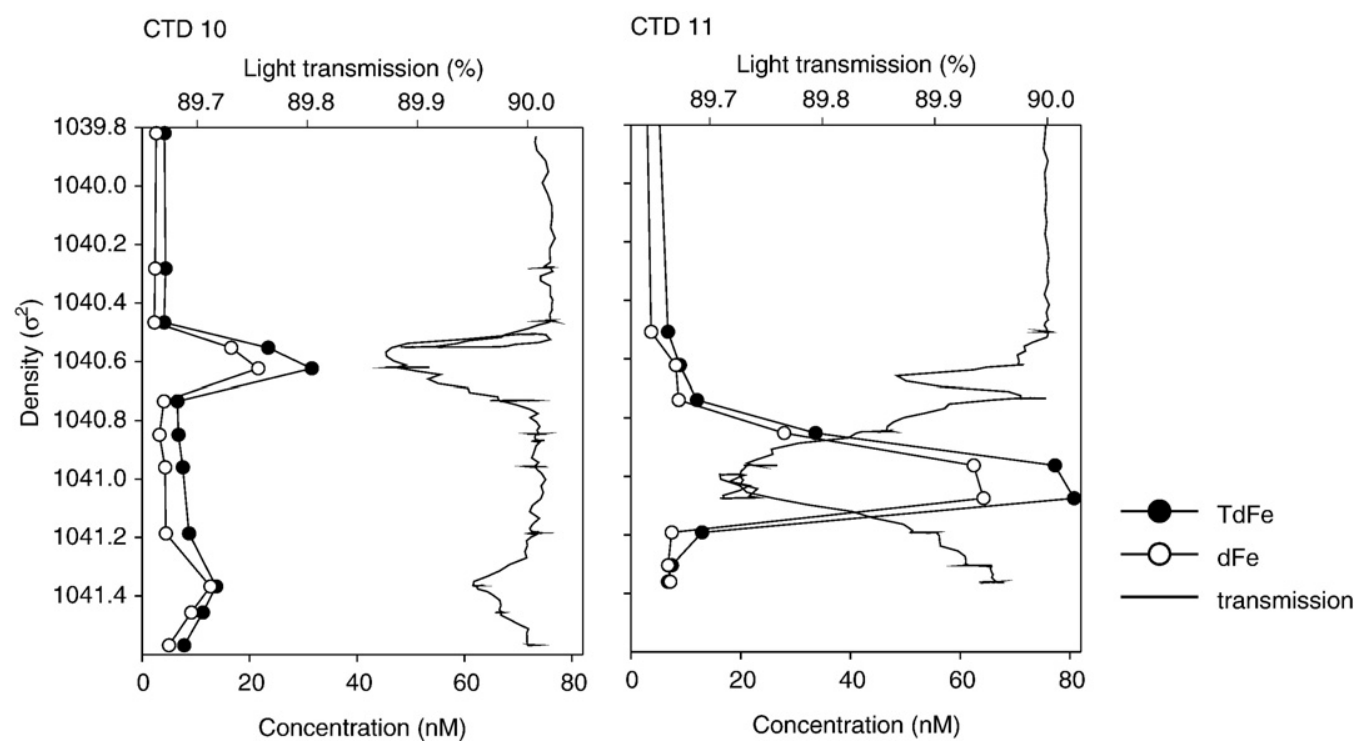

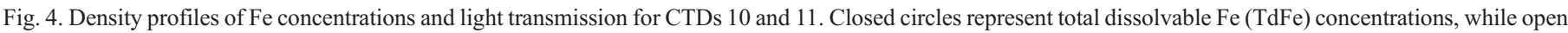

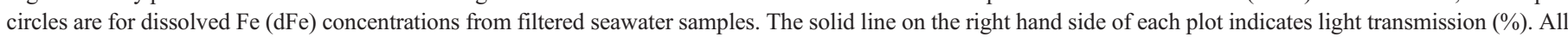
three plumes lie on different isopycnal surfaces indicating that they are each sourced from a distinct high-temperature vent-system in the $5^{\circ} \mathrm{S}$ ridge-segment. 
Table 3

Calculation of $\mathrm{Fe}$ (II) oxidation rates at $5^{\circ} \mathrm{S}$ compared to TAG using the same method of Field and Sherrell (2000)

\begin{tabular}{|c|c|c|c|c|c|c|c|c|}
\hline $\begin{array}{l}\text { Depth } \\
(m)\end{array}$ & $\begin{array}{l}\text { Temp } \\
\left({ }^{\circ} \mathrm{C}\right)\end{array}$ & Salinity & $\begin{array}{l}\mathrm{O}_{2} \\
(\mu \mathrm{mol} \mathrm{kg})^{-1}\end{array}$ & $\mathrm{pH}_{\mathrm{sws}}{ }^{\mathrm{c}}$ & $\mathrm{pK}_{\mathrm{w}}{ }^{\mathrm{c}}$ & $\mathrm{pOH}^{\mathrm{d}}$ & $K_{1}{ }^{\mathrm{e}}$ & $\begin{array}{l}\text { Fe(II) half life } \\
\text { (h) }\end{array}$ \\
\hline \multicolumn{9}{|c|}{$5^{\circ} \mathrm{S}$ (Red Lion) $4^{\circ} 47.83^{\prime} S 12^{\circ} 22.60^{\prime} \mathrm{W}^{\mathrm{a}}$} \\
\hline 2700 & 2.5 & 34.91 & 242 & 7.964 & 14.082 & 6.118 & 0.0255 & 0.45 \\
\hline \multicolumn{9}{|c|}{ TAG $26^{\circ} 08.20^{\prime} N 44^{\circ} 49.5^{\prime} W^{\mathrm{b}}$} \\
\hline 2985 & 2.8 & 34.94 & 255 & 7.945 & 14.057 & 6.112 & 0.0279 & 0.41 \\
\hline
\end{tabular}

${ }^{a}$ Oxygen data sourced from WOCE hydrographic program, Line number AR15, 316 N142_3, station 55. Other data sourced from CD169 CTD station 10.

${ }^{\mathrm{b}}$ Oxygen, temperature and salinity data sourced from WOCE hydrographic program, Line number A05, 29HE06_1, station 73.

${ }^{\mathrm{c}} \mathrm{pH}$ and $\mathrm{pK}_{\mathrm{w}}$ calculated using Lewis, E., and D. W. R. Wallace. 1998. Program Developed for CO2 System Calculations. ORNL/CDIAC-105. Carbon Dioxide Information Analysis Center, Oak Ridge National Laboratory, U.S. Department of Energy, Oak Ridge, Tennessee. Silicate, phosphate, $\mathrm{TCO}_{2}$ and TAlk data used in the program were sourced as above.

${ }^{\mathrm{d}} \mathrm{pOH}=\mathrm{pK}_{\mathrm{w}}-\mathrm{pH}$.

e $\log k=21.56-1545 / T-3.29 \mathrm{I}^{1 / 2}+1.52 \mathrm{I}$ where $I=19.9201 \times S /\left(10^{3}-1.00488 \times S\right)$, where, $S$ is salinity and $T$ is temperature in Kelvin (Millero et al., 1987$), k_{1}=$ $k\left[\mathrm{OH}^{-}\right]^{2}\left[\mathrm{O}_{2}\right]$.

notable about this station, however, is not that the plume is rich in particulate material but that it retains very high concentrations $(\sim 20 \mathrm{nM})$ of dissolved $\mathrm{Fe}$ - approximately 30 times higher than typical deep-ocean values (Bergquist and Boyle, 2006). For a strong along-axis current of $10 \mathrm{~cm} \mathrm{~s}^{-1}$ (not uncommon in the deep Mid-Atlantic Ridge rift-valley (Thurnherr et al., 2002)), a minimum advection time to this location can be calculated of $\sim 7 \mathrm{~h}$. This is long compared to the predicted dissolved $\mathrm{Fe}(\mathrm{II})$ oxidation rate for the local deep water-column (Millero et al., 1987; Millero, 1998) which has a calculated dissolved Fe(II) oxidation half-life of $\sim 27$ min (Table 3) - nearly identical to that for the TAG hydrothermal field at $26^{\circ} \mathrm{N}$, Mid-Atlantic Ridge (Field and Sherrell, 2000).

For a typical dissolved Fe vent-fluid concentration of $1 \mathrm{mM}$, we can predict a $10^{4}$-fold dilution during buoyant plume mixing to $\sim 100 \mathrm{nM}$ at the top of the buoyant plume (McDuff, 1995) followed by a further reduction to the observed concentrations at CTD 7 of $\sim 20 \mathrm{nM}$ within just $\sim 1 \mathrm{~h}$ ( 2 half-lives). By contrast, the advection time to CTD 7 from the nearest vent-site at $10 \mathrm{~cm} \mathrm{~s}^{-1}$ would be equivalent to $15-16$ dissolved Fe(II) half-lives. To travel the same distance within just $1 \mathrm{~h}$ would require advection at quite unprecedented deep-ocean current velocities of $\sim 70 \mathrm{~cm} \mathrm{~s}^{-1}$.

A more plausible explanation for the higher-than-predicted dissolved Fe concentrations is that our operationally defined $(<0.4 \mu \mathrm{m})$ dissolved $\mathrm{Fe}$ fraction includes both truly dissolved and colloidal $\mathrm{Fe}$ species. In the open oligotrophic Atlantic and Pacific Oceans it has been argued that a significant proportion of dissolved $\mathrm{Fe}$ is actually in colloidal form (Wu et al., 2001) and it is known that total dissolvable $\mathrm{Fe}$ (i.e. dissolved and particulate forms together) can be advected quantitatively within nonbuoyant plumes over 4-5 km length-scales (Hudson et al., 1986; Klinkhammer and Hudson, 1986; German et al., submitted for publication). There is also the possibility that a significant proportion of the dissolved $\mathrm{Fe}$ present within the $5^{\circ} \mathrm{S}$ hydrothermal plume may have been stabilised as soluble organic $\mathrm{Fe}$ complexes, similar to the stabilised dissolved $\mathrm{Fe}$ complexes present in the open-ocean, as well as stable dissolved Fe-sulfide clusters, formed immediately post-venting (Luther et al., 2001).

\subsection{Fe speciation in the plume}

To investigate whether stabilising ligand complexes are, indeed, present in non-buoyant hydrothermal plumes, we have carried out speciation studies across the shallower plume at CTD station 10. As noted above, Fe concentrations in the centre of the plume were so high that they saturated any ligands present. For samples immediately above and below the plume core, however, our analyses have revealed ligand concentrations in the range 2.5-4.2 $\mathrm{nM}$ (Table 2), compared to $0.7-1.4 \mathrm{nM}$ in the open ocean (Boye et al., 2001; Cullen et al., 2006). These concentrations are 3.6 to 6.0 times higher than open-ocean dissolved $\mathrm{Fe}$ concentrations ( $0.7 \mathrm{nM}$ (Bergquist and Boyle, 2006)). The total ligand concentrations detected are not solely expected to be the result of organic complexation, as the presence of complex inorganic $\mathrm{Fe}$-stabilising ligands, should also be expected to occur as part of this stabilised Fe fraction (Town and van Leeuwen, 2005). Between $2825 \mathrm{~m}$ and $2800 \mathrm{~m}$, the ligand concentration increased from $3.4 \mathrm{nM}$ to $4.2 \mathrm{nM}$ toward the plume-core. This mimics the gradient seen for Mn $v s$. depth at CTD 10 (Fig. 3), which increases from 3.3 to $4.7 \mathrm{nM}$ over the same depth range, indicative of mixing between the plume's interior and the surrounding (both overlying and underlying) water column.

Of course, as demonstrated in the Atlantic Ocean, a fraction of this dissolved Fe is likely to be colloidal (Wu et al., 2001; Cullen et al., 2006). In a recent $\mathrm{Fe}$ enrichment experiment in the Southern Ocean (Boye et al., 2005) it was reported that immediately after $\mathrm{Fe}$ addition, the concentration of ligands in the $<200 \mathrm{kDa}$ fraction (soluble) only represented $55 \%$ of the total ligand present in the $<0.2 \mu \mathrm{m}$ fraction (soluble and colloidal). However, whatever their size-distribution and chemical nature, the "coarser" ligands were still stabilising $\mathrm{Fe}$ and preventing aggregation of large particles that would remove $\mathrm{Fe}$ to the seafloor (Boye et al., 2005). Further, what is at least as important to note is that even at their most dilute, the concentrations of ligand measured on the fringes of the non-buoyant plume in CTD 10 were significantly higher than typical deep-ocean values. While higher concentrations have been measured in 
near-shore waters, both in the NW Atlantic Ocean and the Black Sea (Witter and Luther, 1998; Witter et al., 2000), Cullen et al. (2006) measured much lower ligand concentrations, down to $1.22 \mathrm{nM}$, in deep-waters closer to our study site, in the open South Atlantic Ocean. We argue, therefore, the simple entrainment of deep open-ocean waters into buoyant hydrothermal plumes at $5^{\circ} \mathrm{S}$ cannot account for the elevated levels of ligand at near-plume height reported here. Rather, some additional source must exist. Further, because ligand concentrations increased toward the core of the non-buoyant plume, the ligand source must be present during the process of plume emplacement and cannot be attributed, for example, to zooplankton that graze on the fringes of non-buoyant plumes (Burd et al., 1992; Vereshchaka and Vinogradov, 1999; Cowen et al., 2001) because any ligands sourced from outside the plume-core would be expected to exhibit a decreasing concentration inward.

Equally, it does not seem plausible that end-member ventfluids should be the source of the high organic ligand concentrations measured: complex organic molecules are only stable in high-temperature vent fluids under exceptional circumstances such as sediment-hosted hydrothermal systems (e.g. Guaymas basin, Middle Valley, Juan de Fuca Ridge)(Pearson et al., 2005; Cruse and Seewald, 2006) or, in bare-rock environments, at ultramafic-hosted vents sites such as the Rainbow hydrothermal field, MAR (Holm and Charlou, 2001). The $5^{\circ} \mathrm{S}$ hydrothermal vents, by contrast, are hosted in freshly-erupted basaltic lavas and show none of those characteristics (Haase et al., 2007).

The most likely source of dissolved organic matter that may be entrained into the hydrothermal plume, therefore, is from areas of diffuse flow adjacent to the high-temperature vent-sites. Diffuse systems, typically, host the most abundant chemosynthetic communities associated with seafloor hydrothermal venting and within these environmental niches, dissolved organic carbon concentrations have been observed that reach concentrations of 39-69 $\mu \mathrm{M}$, up to approximately double background deep-ocean waters (Lang et al., 2006). In support of this argument, organic copper-binding ligand concentrations have recently been reported for diffuse-flow fluids from above a mussel field south of Lilliput $\left(9^{\circ} 33.01^{\prime} \mathrm{S}, 13^{\circ} 12.38^{\prime} \mathrm{W}\right)($ Koschinsky et al., 2006a) that reach concentrations of up to $0.6 \mu \mathrm{M}$ (Sander et al., 2007). These ligand concentrations represent an 8-fold excess over the total $\mathrm{Cu}$ present, indicating an abundance of free ligand sites that could potentially be available for $\mathrm{Fe}$ complexation if such fluids were, indeed, entrained into an adjacent, buoyant hydrothermal plume.

Such early entrainment of organic matter, into the base of buoyant hydrothermal plumes, would be important because we predict that organic complexation of Fe(III) must take place immediately after the oxidation of dissolved $\mathrm{Fe}$ (II) and before $\mathrm{Fe}$ could precipitate in the form of crystalline hydrolysis products. Because $\mathrm{Fe}$ (II) oxidation kinetics slow progressively along the thermohaline conveyor (Field and Sherrell, 2000; Statham et al., 2005) this implies that the time period for such complexation to occur should increase along the same trajectory from the Atlantic to Indian and Pacific Oceans, as long as there is an excess of ligand available. At our study site complete $\mathrm{Fe}$ (II) oxidation would be predicted to occur in the first few hours after venting (see previous section). Therefore, all complexation with organic ligands should either occur within the buoyant hydrothermal plume or within the youngest portions of the nonbuoyant plume, immediately overlying the vent-site (Rudnicki and Elderfield, 1993; Field and Sherrell, 2000). This would be perfectly feasible if the principal source of ligand were, indeed, from entrainment of diffuse flow waters at the base of the buoyant plume followed by mixing and commencement of Fecomplexation during plume-rise.

There is also the potential for organically complexed $\mathrm{Fe}(\mathrm{II})$ species to be present in the stabilised dissolved $\mathrm{Fe}$ fraction (Hopkinson and Barbeau, 2007). Complexation of Fe(II) would be dominant during buoyant plume rise because of the high abundance of $\mathrm{Fe}$ (II) species leaving the high-temperature hydrothermal vents and diffuse flow areas. The presence of such complexes would reduce the rate of $\mathrm{Fe}$ (II) oxidation enabling the dissolved Fe(II) to be exported to the non-buoyant plume. Fe(II)ligand complexes have already been hypothesised to be present in the vent environments in order for Fe oxidising bacteria to control $\mathrm{Fe}(\mathrm{II})$ oxidation during Fe sulfide dissolution (Edwards et al., 2004). But unfortunately at present no methods exist for the measurement of dissolved Fe(II)-ligand complexes.

\subsection{Ligand-stabilised hydrothermal $\mathrm{Fe}$ and the global mass balance}

The most recent estimation of the global volume flux for seawater passing through high-temperature hydrothermal venting is $7.2 \times 10^{12} \mathrm{~kg} \mathrm{y}^{-1}$, calculated using chemical and isotopic mass balances of the element thallium (Nielsen et al., 2006). Allowing for $\sim 10^{4}$-fold dilution in buoyant hydrothermal plumes (McDuff, 1995), this equates to a $7.2 \times 10^{16} \mathrm{~kg} \mathrm{y}^{-1}$ flux of combined vent-fluid and oceanic deep-water entering nonbuoyant hydrothermal plumes, worldwide. If we took our new measurements of stabilising Fe ligands $(4.2 \mathrm{nM})$ at CTD 10 as representative of young non-buoyant plumes in general, with the assumption that in the core of the plume these ligand concentrations may be even higher (because of less dilution), this would imply that the flux of such stabilising ligands through hydrothermal plumes would be at least $3.0 \times 10^{8} \mathrm{~mol} \mathrm{y}^{-1}$. Assuming 1:1 complexation, this would be accompanied by a global flux of hydrothermal Fe, stabilised by entrained ligands, which would also be estimated as $>3.0 \times 10^{8} \mathrm{~mol} \mathrm{y}^{-1}$. This compares to a gross hydrothermal Fe flux of $7.2 \times 10^{9} \mathrm{~mol} \mathrm{y}^{-1}$ assuming a nominal vent-fluid dissolved $\mathrm{Fe}$ concentration of $1 \mathrm{mM}$ (Range $=5.4-47 \times 10^{9} \mathrm{~mol} \mathrm{y}^{-1}$ for end-member Fe concentrations of 0.75-6.5 mM (Elderfield and Schultz, 1996)) -i.e our predicted flux of ligand-stabilised Fe passing through hydrothermal plumes would only represent $\sim 4 \%$ of the global total (Range: $0.6-5.6 \%$ ). Even so, this small proportion of the gross hydrothermal $\mathrm{Fe}$ flux, could still have a significant impact on global deep-ocean dissolved Fe budgets.

The volume of the global deep-ocean is $2.6 \times 10^{20} \mathrm{~L}$ (Libes, 1992). Assuming a uniform deep-ocean dissolved Fe concentration of $0.7 \mathrm{nM}$ (Bergquist and Boyle, 2006), we can calculate an instantaneous standing stock of deep-ocean dissolved Fe of $1.9 \times 10^{11}$ mol of which $30-70 \%$ is potentially present in colloidal form (cf this study)(Wu et al., 2001). To maintain steady state, 


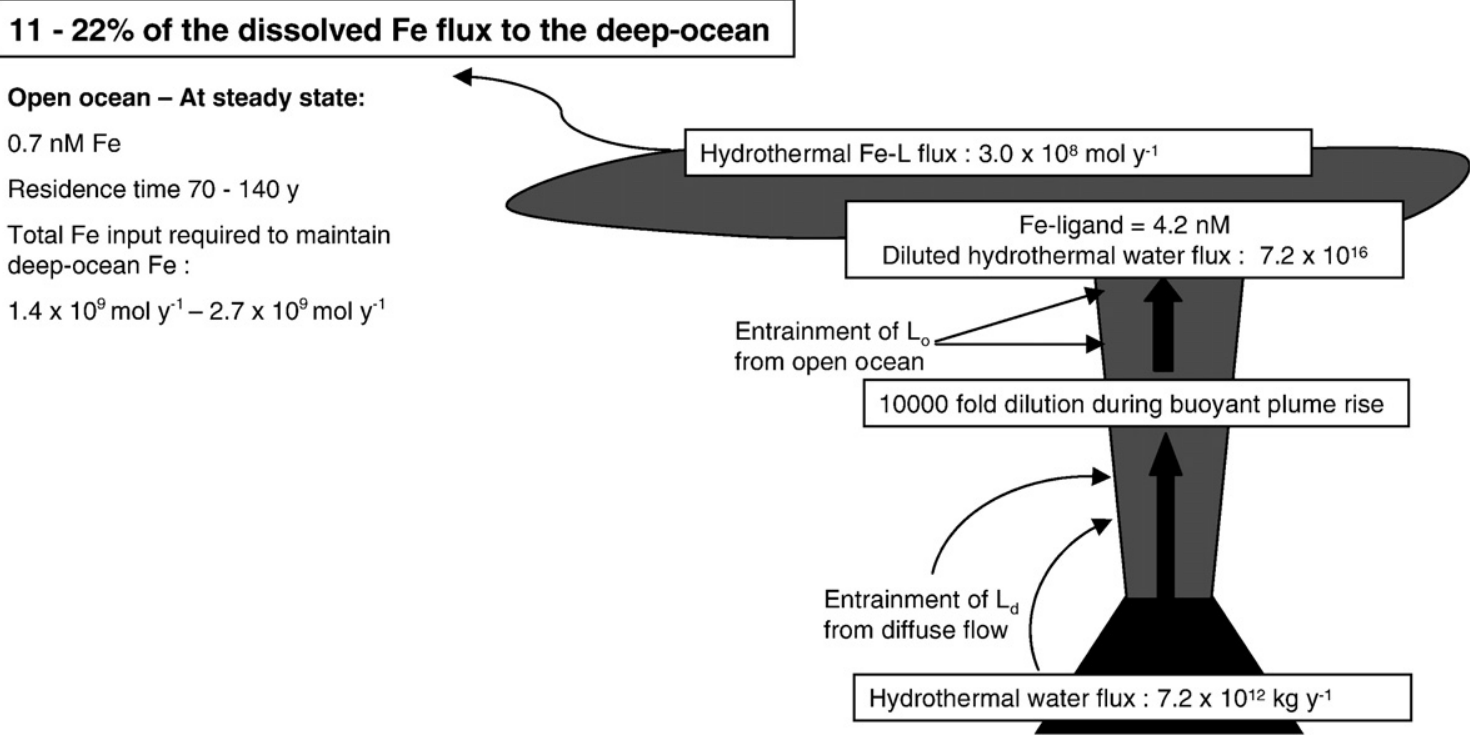

Fig. 5. Flux diagram for hydrothermal inputs of Fe to the deep-ocean (see text for explanation). $L_{\mathrm{o}}$ is the ligand entrained from the open ocean and $L_{\mathrm{d}}$ is the ligand entrained from the diffuse flow areas.

with dissolved Fe residence times of 70-140 y (Bruland et al., 1994), the required input flux of $\mathrm{Fe}$ to the oceans is $1.4-2.7 \times$ $10^{9} \mathrm{~mol} \mathrm{y}^{-1}$. Combining the above, we can conclude that the predicted ligand-stabilised flux of Fe from hydrothermal systems, which likely represents no more than $\sim 4 \%$ of the global hydrothermal discharge, is nevertheless sufficient to supply some 11$22 \%$ of the dissolved Fe present throughout the global deepocean. This mass balance is summarised in Fig. 5 .

While our work is only preliminary - there has been no prior investigation of Fe-ligand interactions in deep-sea non-buoyant hydrothermal plumes - we believe the results are significant. If hydrothermally-sourced $\mathrm{Fe}$ is prevalent throughout the deepocean then the possibility exists that seafloor hydrothermal venting, which interacts with the entire volume of the deepocean over timescales of a few thousand years (Elderfield and Schultz, 1996) might be more closely coupled than has previously been recognised with upper ocean processes - where Fe can act as a limiting micronutrient in HNLC regions (Morel et al., 2004). Key to this argument is the recent demonstration that mantle sourced dissolved ${ }^{3} \mathrm{He}$ from non-buoyant hydrothermal plumes overlying the southern East Pacific Rise (where hydrothermal plumes are at their most abundant (Baker and German, 2004)) is, indeed, upwelled to the surface waters of the Southern Ocean, as a simple result of flow along isopycnal surfaces (Jenkins et al., 2007; Winckler et al., 2007). Of immediate future interest, therefore, is whether this same transport mechanism, from hydrothermal plume depths to surface ocean interactions might also be important for other dissolved hydrothermal tracers.

\section{Summary}

We have investigated the fate of Fe in a series of non-buoyant hydrothermal plumes dispersing away from vents near $5^{\circ} \mathrm{S}$, Mid-Atlantic Ridge and found that the dissolved Fe concentrations at plume height are higher than would be predicted from dissolved Fe(II) oxidation-rates alone. Detailed speciation studies have revealed that a fraction of the dissolved Fe present is stabilised by Fe-complexing ligands and measurements of those ligand concentrations lead us to calculate that $\sim 4 \%$ of the total $\mathrm{Fe}$ released from the $5^{\circ} \mathrm{S}$ vents may be stabilised in this way. If the results reported here were representative of all hydrothermal systems, it would imply that high-temperature venting may provide the source for $11-22 \%$ of the global deepocean dissolved Fe budget and, hence, that submarine venting may provide an important, previously-overlooked, source of dissolved Fe in global-ocean biogeochemical cycles.

\section{Acknowledgements}

We thank the captain, crew and UKORS team on board the RRS Charles Darwin, CD169, who contributed to the success of this work and to Alan Evans for help creating the location map (Fig. 1). We also thank two anonymous reviewers whose useful comments have improved this manuscript. This study was funded by NERC PhD studentship, NER/S/A/2004/12631 and supplemented by core strategic funding to NOC's NERC Research Division.

\section{References}

Baker, E.T., German, C.R., 2004. On the global distribution of hydrothermal vent fields. In: German, C.R., Lin, J., Parson, L.M. (Eds.), Mid-ocean Ridges: Hydrothermal Interactions Between the Lithosphere and Oceans. Geophysical Monograph Series. American Geophysical Union, Washington, D.C., pp. 245-266.

Bergquist, B.A., Boyle, E.A., 2006. Dissolved iron in the tropical and subtropical Atlantic Ocean. Glob. Biogeochem. Cycles 20, GB1015 (MAR 18 2006).

Boye, M., Van den Berg, C.M.G., de Jong, J.T.M., Leach, H., Croot, P., de Baar, H.J.W., 2001. Organic complexation of iron in the Southern Ocean. DeepSea Res., Part 1, Oceanogr. Res. Pap. 48, 1477-1497.

Boye, M., Nishioka, J., Croot, P.L., Laan, P., Timmermans, K.R., de Baar, H.J.W., 2005. Major deviations of iron complexation during 22 days of a mesoscale iron enrichment in the open Southern Ocean. Mar. Chem. 96, 257-271. 
Boyle, E.A., Bergquist, B.A., Kayser, R.A., Mahowald, N., 2005. Iron, manganese, and lead at Hawaii Ocean Time-series station ALOHA: temporal variability and an intermediate water hydrothermal plume. Geochim. Cosmochim. Acta 69, 5165-5166.

Bruland, K.W., Franks, R.P., Knauer, G.A., Martin, J.H., 1979. Sampling and analytical methods for the determination of copper, cadmium, zinc, and nickel at the nanogram per liter level in sea-water. Anal. Chim. Acta 105, 233-245.

Bruland, K.W., Orians, K.J., Cowen, J.P., 1994. Reactive trace-metals in the stratified central North Pacific. Geochim. Cosmochim. Acta 58, 3171-3182.

Burd, B.J., Thomson, R.E., Jamieson, G.S., 1992. Composition of a deep scattering layer overlying a mid-ocean ridge hydrothermal plume. Mar. Biol. 113, 517-526.

Coale, K.H., Chin, C.S., Massoth, G.J., Johnson, K.S., Baker, E.T., 1991. In-situ chemical mapping of dissolved iron and manganese in hydrothermal plumes. Nature 352, 325-328.

Cowen, J.P., Bertram, M.A., Wakeham, S.G., Thomson, R.E., Lavelle, J.W., Baker, E.T., Feely, R.A., 2001. Ascending and descending particle flux from hydrothermal plumes at Endeavour Segment, Juan de Fuca Ridge. Deep-Sea Res., Part 1, Oceanogr. Res. Pap. 48, 1093-1120.

Croot, P.L., Johansson, M., 2000. Determination of iron speciation by cathodic stripping voltammetry in seawater using the competing ligand 2-(2-thiazolylazo)p-cresol (TAC). Electroanalysis 12, 565-576.

Cruse, A.M., Seewald, J.S., 2006. Geochemistry of low-molecular weight hydrocarbons in hydrothermal fluids from Middle Valley, northern Juan de Fuca Ridge. Geochim. Cosmochim. Acta 70, 2073-2092.

Cullen, J.T., Bergquist, B.A., Moffett, J.W., 2006. Thermodynamic characterization of the partitioning of iron between soluble and colloidal species in the Atlantic Ocean. Mar. Chem. 98, 295-303.

Donat, J.R., Bruland, K.W., 1988. Direct determination of dissolved cobalt and nickel in seawater by differential pulse cathodic stripping voltammetry preceded by adsorptive collection of cyclohexane-1,2-dione dioxime complexes. Anal. Chem. 60, 240-244.

Edwards, K.J., Bach, W., McCollom, T.M., Rogers, D.R., 2004. Neutrophilic iron-oxidizing bacteria in the ocean: their habitats, diversity, and roles in mineral deposition, rock alteration, and biomass production in the deep-sea. Geomicrobiol. J. 21, 393-404.

Elderfield, H., Schultz, A., 1996. Mid-ocean ridge hydrothermal fluxes and the chemical composition of the ocean. Ann. Rev. Earth Planet. Sci. 24, 191-224.

Feely, R.A., Lewison, M., Massoth, G.J., Robertbaldo, G., Lavelle, J.W., Byrne, R.H., Von Damm, K.L., Curl, H.C., 1987. Composition and dissolution of black smoker particulates from active vents on the Juan-De-Fuca Ridge. J. Geophys. Res.-Solid Earth Planets 92, 11347-11363.

Field, M.P., Sherrell, R.M., 2000. Dissolved and particulate Fe in a hydrothermal plume at 9 degrees 45' N, East Pacific Rise: slow Fe (II) oxidation kinetics in Pacific plumes. Geochim. Cosmochim. Acta 64, 619-628.

German, C.R., Parson, L.M., 2005. RRS Charles Darwin Cruise 169. 17 Feb-19 Mar 2005 Hydrothermal Exploration of the southern Mid-Atlantic Ridge (Cruise Report, No. 6).

German, C.R., Campbell, A.C., Edmond, J.M., 1991. Hydrothermal scavenging at the Mid-Atlantic Ridge: modification of trace element dissolved fluxes. Earth Planet. Sci. Lett. 107, 101-114.

German, C.R., Klinkhammer, G.P., Rudnicki, M.D., 1996. The Rainbow hydrothermal plume, 36 degrees $15^{\prime} \mathrm{N}$, MAR. Geophys. Res. Lett. 23, 2979-2982.

German, C.R., Bennett, S.A., Connelly, D.P., Evans, A.J., Murton, B.J., Parson, L.M., Prien, R.D., Ramirez-Llodra, E.Z., Jakuba, M., Shank, T.M., Yoerger, D.R., Walker, S.L., Baker, E.T. and Nakamura, K., submitted for publication. Hydrothermal activity on the southern Mid-Atlantic Ridge: Tectonically and volcanically controlled venting, $4-5$ degrees S. Earth and Planetary Science Letters.

German, C.R., Thurnherr, A.M., Radford-Knoery, J., Charlou, J.L., JeanBaptiste, P. and Edmonds, H.N., submitted for publication. Export heat and chemical fluxes from submarine venting to the oceans: the Rainbow hydrothermal field Mid-Atlantic Ridge. Nature Geoscience.

Gledhill, M., Van den Berg, C.M.G., 1994. Determination of complexation of iron(III) with natural organic complexing ligands in seawater using cathodic stripping voltammetry. Mar. Chem. 47, 41-54.
Gledhill, M., Van den Berg, C.M.G., 1995. Measurement of the redox speciation of iron in seawater by catalytic cathodic stripping voltammetry. Mar. Chem. 50 , $51-61$.

Haase, K.M., Petersen, S., Koschinsky, A., Seifert, R., Devey, C.W., Keir, R., Lackschewitz, K.S., Melchert, B., Perner, M., Schmale, O., Suling, J., Dubilier, N., Zielinski, F., Fretzdorff, S., Garbe-Schonberg, D., Westernstroer, U., German, C.R., Shank, T.M., Yoerger, D., Giere, O., Kuever, J., Marbler, H., Mawick, J., Mertens, C., Stober, U., Ostertag-Henning, C., Paulick, H., Peters, M., Strauss, H., Sander, S., Stecher, J., Warmuth, M., Weber, S., 2007. Young volcanism and related hydrothermal activity at 5 degrees $\mathrm{S}$ on the slow-spreading southern Mid-Atlantic Ridge. Geochem. Geophys. Geosyst. 8, Q11002 (NOV 13 2007).

Holm, N.G., Charlou, J.L., 2001. Initial indications of abiotic formation of hydrocarbons in the Rainbow ultramafic hydrothermal system, Mid-Atlantic Ridge. Earth Planet. Sci. Lett. 191, 1-8.

Hopkinson, B.M., Barbeau, K.A., 2007. Organic and redox speciation of iron in the eastern tropical North Pacific suboxic zone. Mar. Chem. 106, 2-17.

Hudson, A., Bender, M.L., Graham, D.W., 1986. Iron enrichments in hydrothermal plumes over the East Pacific Rise. Earth Planet. Sci. Lett. 79, 250-254.

Jenkins, W.J., Naveira, A., Schlosser, P., Lott, D.E., Newton, R., 2007. Oceanic volcanic ${ }^{3} \mathrm{He}$ : where is it going? EOS, Transactions, American Geophysical Union, 88, Fall Meet, Suppl., Abstract OS32A-02.

Klinkhammer, G., Hudson, A., 1986. Dispersal patterns for hydrothermal plumes in the South-Pacific using manganese as a tracer. Earth Planet. Sci. Lett. 79, 241-249.

Koschinsky, A., Billings, A., Devey, C., Dubilier, N., Duester, A., Edge, D., Garbe-Schönberg, D., German, C.R., Giere, O., Keir, R., Lackschewitz, K., Mai, H., Marbler, H., Mawick, J., Melchert, B., Mertens, C., Peters, M., Sander, S., Schmale, O., Schmidt, W., Seifert, R., Seiter, C., Stöber, U., Suck, I., Walter, M., Weber, S., Yoerger, D.R., Zarrouk, M., Zielinski, F., 2006a. Discovery of new hydrothermal vents on the Southern Mid-Atlantic Ridge $\left(4^{\circ} \mathrm{S}-10^{\circ} \mathrm{S}\right)$ during cruise M68/1. InterRidge News, $15,9-15$.

Koschinsky, A., Devey, C., Garbe-Schonberg, D., German, C.R., Yoerger, D.R., Shank, T.M., 2006b. Hydrothermal Exploration of the Mid-Atlantic Ridge, $5-10^{\circ} \mathrm{S}$, using the AUV ABE and the ROV Quest-a brief overview of RV Meteor Cruise M68/1. EOS, Transactions, American Geophysical Union, 87, Fall Meet, Suppl., Abstract OS34A-05.

Lang, S.Q., Butterfield, D.A., Lilley, M.D., Johnson, H.P., Hedges, J.I., 2006. Dissolved organic carbon in ridge-axis and ridge-flank hydrothermal systems. Geochim. Cosmochim. Acta 70, 3830-3842.

Libes, S.M., 1992. An Introduction to Marine Biogeochemistry. John Wiley \& Sons, Inc.

Lupton, J.E., 1995. Hydrothermal plumes: near and far field. In: Humphris, S.E., Zierenberg, R.A., Mullineaux, L.S., Thomson, R.E. (Eds.), Seafloor Hydrothermal Systems: Physical, Chemical, Biological, and Geological Interactions. Geophysical Monograph, vol. 91. American Geophysical Union, Washington, D.C., pp. 317-346.

Luther, G.W., Rozan, T.F., Taillefert, M., Nuzzio, D.B., Di Meo, C., Shank, T.M., Lutz, R.A., Cary, S.C., 2001. Chemical speciation drives hydrothermal vent ecology. Nature 410, 813-816.

McDuff, R.E., 1995. Physical dynamics of deep sea hydrothermal plumes. In: Humphris, S.E., Zierenberg, R.A., Mullineaux, L.S., Thomson, R.E. (Eds.), Seafloor Hydrothermal Systems: Physical, Chemical, Biological, and Geological Interactions. Geophysical Monograph, vol. 91. American Geophysical Union, Washington, D.C., pp. 357-368.

Millero, F.J., 1998. Solubility of Fe(III) in seawater. Earth Planet. Sci. Lett. 154, 323-329.

Millero, F.J., Sotolongo, S., Izaguirre, M., 1987. The oxidation-kinetics of Fe(II) in seawater. Geochim. Cosmochim. Acta 51, 793-801.

Morel, F.M.M., Milligan, A.J., Saito, M.A., 2004. Marine bioinorganic chemistry: the role of trace metals in the oceanic cycles of major nutrients. In: Elderfield, H. (Ed.), The Oceans and Marine Geochemistry. Treatise on Geochemistry. Elsevier, Oxford, pp. 113-143.

Mottl, M.J., McConachy, T.F., 1990. Chemical processes in buoyant hydrothermal plumes on the East Pacific Rise near 21-degrees-N. Geochim. Cosmochim. Acta 54, 1911-1927.

Nielsen, S.G., Rehkamper, M., Teagle, D.A.H., Butterfield, D.A., Alt, J.C., Halliday, A.N., 2006. Hydrothermal fluid fluxes calculated from the isotopic 
mass balance of thallium in the ocean crust. Earth Planet. Sci. Lett. 251, $120-133$.

Pearson, A., Seewald, J.S., Eglinton, T.I., 2005. Bacterial incorporation of relict carbon in the hydrothermal environment of Guaymas Basin. Geochimic. Cosmochim. Acta 69, 5477-5486.

Pollard, R.T., Sanders, R., Lucas, M.I., Statham, P., 2007. The Crozet Natural Iron Bloom and EXport Experiment (CROZEX). Deep-Sea Res. Part 2, Top. Stud. Oceanogr. 54, 1905-1914.

Rudnicki, M.D., Elderfield, H., 1993. A chemical-model of the buoyant and neutrally buoyant plume above the TAG vent field, 26 degrees-N, MidAtlantic Ridge. Geochim. Cosmochim. Acta 57, 2939-2957.

Rudnicki, M.D., German, C.R., 2002. Temporal variability of the hydrothermal plume above the Kairei vent field, 25 degrees S, Central Indian Ridge. Geochem. Geophys. Geosyst 3, 1010 (Feb 9 2002).

Rudnicki, M.D., James, R.H., Elderfield, H., 1994. Near-field variability of the TAG non-buoyant plume, 26-degrees-N, Mid-Atlantic Ridge. Earth Planet. Sci. Lett. 127, 1-10

Rue, E.L., Bruland, K.W., 1995. Complexation of iron(III) by natural organic ligands in the Central North Pacific as determined by a new competitive ligand equilibration/adsorptive cathodic stripping voltammetric method. Mar. Chem. 50, 117-138.

Rue, E.L., Bruland, K.W., 1997. The role of organic complexation on ambient iron chemistry in the equatorial Pacific Ocean and the response of a mesoscale iron addition experiment. Limnol. Oceanogr. 42, 901-910.

Ruzic, I., 1982. Theoretical aspects of the direct titration of natural-waters and its information yield for trace-metal speciation. Anal. Chim. Acta 140, 99-113.

Sander, S.G., Koschinsky, A., Massoth, G., Stott, M., Hunter, K.A., 2007. Organic complexation of copper in deep-sea hydrothermal vent systems. Environm. Chem. 4, 81-89.

Schmidt, K., Koschinsky, A., Garbe-Schonberg, D., de Carvalho, L.M., Seifert, R., 2007. Geochemistry of hydrothermal fluids from the ultramafic-hosted Logatchev hydrothermal field, $15 \mathrm{~N}$ on the Mid-Atlantic Ridge: temporal and spatial investigation. Chem. Geol. 242, 1-21.

Statham, P.J., 1985. The determination of dissolved manganese and cadmium in sea-water at low nmol $\mathrm{L}^{-1}$ concentrations by chelation and extraction followed by electrothermal atomic-absorption spectrometry. Anal. Chim. Acta $169,149-159$.

Statham, P.J., German, C.R., Connelly, D.P., 2005. Iron(II) distribution and oxidation kinetics in hydrothermal plumes at the Kairei and Edmond vent sites, Indian Ocean. Earth Planet. Sci. Lett. 236, 588-596.

Thurnherr, A.M., Richards, K.J., German, C.R., Lane-Serff, G.F., Speer, K.G., 2002. Flow and mixing in the rift valley of the Mid-Atlantic Ridge. J. Phys Oceanogr. 32, 1763-1778.
Town, R.M., van Leeuwen, H.P., 2005. Reply to comments on "Measuring marine iron(III) complexes by CLE-AdSV". Environ. Chem. 2, 90-93.

Ussher, S.J., Achterberg, E.P., Worsfold, P.J., 2004. Marine biogeochemistry of iron. Environ. Chem. 1, 67-80.

Van den Berg, C.M.G., 1982. Determination of copper complexation with natural organic-ligands in sea-water by equilibration with $\mathrm{MnO}_{2} .1$. Theory. Mar. Chem. 11, 307-322.

Van den Berg, C.M.G., 1995. Evidence for organic complexation of iron in seawater. Mar. Chem. 50, 139-157.

Van den Berg, C.M.G., 2005. Organic iron complexation is real, the theory is used incorrectly. Comment on 'Measuring marine iron(III) complexes by CLE-AdSV'. Environ. Chem. 2, 88-89.

Van den Berg, C.M.G., 2006. Chemical speciation of iron in seawater by cathodic stripping voltammetry with dihydroxynaphthalene. Anal. Chem. 78, 156-163.

Van Dover, C.L., German, C.R., Speer, K.G., Parson, L.M., Vrijenhoek, R.C., 2002. Marine biology - evolution and biogeography of deep-sea vent and seep invertebrates. Science 295, 1253-1257.

van Leeuwen, H.P., Town, R.M., 2005. Kinetic limitations in measuring stabilities of metal complexes by Competitive Ligand Exchange-Adsorptive Stripping Voltammetry (CLE-AdSV). Environ. Sci. Technol. 39, 7217-7225.

Vereshchaka, A.L., Vinogradov, G.M., 1999. Visual observations of the vertical distribution of plankton throughout the water column above Broken Spur vent field, Mid-Atlantic Ridge. Deep-Sea Res., Part 1, Oceanogr. Res. Pap. 46, $1615-1632$

Winckler, G., Newton, R., Schlosser, P., 2007. Evidence for a Hydrothermal Plume in the Pacific Sector of the Southern Ocean. EGU General Assembly, Vienna. (15-20 April 2007. Abstracts., EGU2007-A-05690).

Witter, A.E., Luther, G.W., 1998. Variation in Fe-organic complexation with depth in the Northwestern Atlantic Ocean as determined using a kinetic approach. Mar. Chem. 62, 241-258

Witter, A.E., Hutchins, D.A., Butler, A., Luther, G.W., 2000. Determination of conditional stability constants and kinetic constants for strong model Febinding ligands in seawater. Mar. Chem. 69, 1-17.

Wu, J., Luther III, G.W., 1995. Complexation of Fe(III) by natural organic ligands in the Northwest Atlantic Ocean by a competitive ligand equilibration method and a kinetic approach. Mar. Chem. 50, 159-177.

Wu, J.F., Boyle, E., Sunda, W., Wen, L.S., 2001. Soluble and colloidal iron in the oligotrophic North Atlantic and North Pacific. Science 293, 847-849. 